\title{
Antibacterial Activity of Cyanobacteria Dolichospermum affine Isolated from Freshwater
}

\author{
Dilek Yalçın ${ }^{1}$ (i)
}

Cite this article as: Yalcin, D. (2020). Antibacterial activity of cyanobacteria Dolichospermum affine isolated from freshwater. Aquatic Sciences and Engineering, 35(3), 83-88.

ORCID IDs of the author: D.Y. 0000-0003-2127-8186

${ }^{1}$ Gazi University, Faculty of Education, Department of Biology, Ankara, Turkey

Submitted:

19.11.2019

Revision Requested:

11.02.2020

Revision Requested: 15.02.2020

Accepted:

05.04.2020

Online published:

20.05.2020

Correspondence:

Dilek Yalçın

E-mail:

dilekduygu06@hotmail.com

CCopyright 2020 by Aquatic Sciences and Engineering Available online at

https://dergipark.org.tr/ase

\begin{abstract}
Cyanobacteria are known for their potential for antibacterial activity against a variety of pathogens, which are of medicinal importance in drug development. In addition, Cyanobacterial species produce various secondary metabolites that are used as dye and pigmentation and food additives. Cyanobacteria Dolichospermum affine (Lemmermann) Wacklin, L. Hoffmann \& Komárek was isolated from freshwater resources and its antimicrobial effect was studied. Chloroform, methanol and water extracts of $D$. affine were tested to investigate their efficiency against five pathogenic bacterial strains [Pseudomonas aeruginosa (ATCC 27853), Shigella dysenteriae (ATCC 11835), Escherichia coli (ATCC 25924), Staphylococcus aureus (ATCC 29213) and Bacillus subtilis (ATCC 6633)]. The antimicrobial test was determined using the disk diffusion method. The antimicrobial activities of $D$. affine extracts were measured using the diameter of the inhibition zone (DIZ) of the pathogen microorganisms. The results showed that B. subtilis and E.coli were more sensitive, while $S$. aureus and $P$. aeruginosa showed more intermediate results. The highest antimicrobial activity was measured against $E$. coli $(D I Z=13.9 \pm 0.05 \mathrm{~mm}$ - methanol), followed by $B$. subtilis ( $\mathrm{DIZ}=13.6 \pm 0.05 \mathrm{~mm}$ methanol). The lowest antibacterial effect of $D$. affine extracts were observed against $P$. aeruginosa ( $D I Z=11.7 \pm 0.02 \mathrm{~mm}$ - chloroform) and $S$. aureus ( $D I Z=12.2 \pm 0.03 \mathrm{~mm}$ - chloroform). The Gram-negative bacteria $S$. dysenteria exhibited no zone of inhibition. The aqueous extract showed poor activities against the tested pathogenic bacteria. Therefore, this study revealed that $D$. affine extracts would be a promising natural resource for new antibiotics and further research would be needed.
\end{abstract}

Keywords: Cyanobacteria, Dolichospermum affine, antibacterial activity, zone of inhibition

\section{INTRODUCTION}

Algae are organisms that live in both aquatic and terrestrial environments and in a wide variety of habitats, there are also numerous species and they are the primary producers of ecosystems. The components produced by algae are antioxidants and pigments (including fucoxanthine, carotenoids, lutein, b-carotene, astaxanthin and phycobilliproteins), long chain polyunsaturated fatty acids (LC-PUFA) and proteins (essential amino acids methionine, threonine and tryptophan). These secondary metabolites have wide applications in food, feed, agricultural and pharmaceutical industries (Gouveia, 2014; Walk- er, Purton, \& Becker, 2005; Brennan \& Owened, 2010). Today, the use of biomedical and pharmacological potentials of secondary algal metabolites in algal biotechnology is a relatively new trend (Lorenz \& Cysewski, 2000; Walker et al., 2005). Naturally active compounds found in algae biomass have different biological properties such as cytotoxic, antibiotic, antioxidant, antifungal, anti-inflammatory and antihelminthic (Pulz \& Gross, 2004; Gouveia, Batista, Sousa, Raymundo, \& Bandarra, 2008; Plaza, Santoyo, \& Jaime, 2010; Patil, Patil, Mahajan, \& Mahajan, 2011). Algae are also used as biomolecule and biomass sources in fish farming, which can increase the nutritional value of foods or provide 
additional health benefits (Mulbry, Kondrad, \& Buyer, 2008). They are also used in bioremediation applications and as a biofertilizer because of their nitrogen fixation (Demir, 2011). Today, the most important future use of biomass obtained from algae is thought to be production of biofuels as a renewable energy source (Converti, Casazza, Ortiz, Perego, \& Borghi, 2009; Demirbas, 2010).

Cyanobacteria were the first photosynthetic organisms living in the seas 3.5 billion years ago, capable of photosynthesis and having prokaryotic cell structure. Due to their physiological flexibility and long evolutionary backgrounds, they are found in a wide variety of ecosystems (Weis \& Pang, 2010). They show distinct morphological differences for species as well as single-celled or filamentous forms. The cell size of cyanobacteria is in the range of $0.5-1 \mu \mathrm{m}$ to $40 \mu \mathrm{m}$. It is capable of synthesizing chlorophyll-a and at least one phycobiline as a pigment. Phycocyanin, which belongs to the phycobilin group, is blue in color and is the cause of the blue-green color of most cyanobacteria with chlorophyll-a (Madigan, Martinko, Stahl, \& Clark, 2012). An important feature of some species of cyanobacteria is the ability to fix atmospheric nitrogen $\left(\mathrm{N}_{2}\right)$. Cyanobacteria species that fix nitrogen are generally in filament form and make $\mathrm{N}_{2}$ fixation by a small number of specialized cells called "Heterocyst" (Whitton, 2000).

In recent years, interest in biologically active substances from cyanobacteria has increased. Various studies have demonstrated that cyanobacterial secondary metabolites have hypocholesterolemic properties, enzyme inhibitor and other pharmacological effects (Abobaker \& Elsalhin, 2019). Various types of cyanobacteria are known to produce intracellular and extracellular metabolites with antibacterial and antifungal properties (Kreitlow, Mundt, \& Lindequist, 1999). These natural products are used in the production of raw pharmaceutical materials and as structural models in the synthetic molecules (Gault \& Marler, 2009).

Bacterial infections cause major diseases worldwide, leading to high mortality rates in humans and animals. Antimicrobial agents are widely used in the treatment of bacterial infections, but bacteria can become resistant to existing drugs. For this reason, researchers have begun to search for natural compounds in order to discover new antibacterial compounds (Taskin, Ozturk, Taskin, \& Kurt, 2007). Cyanobacteria are seen as promising biological resources in this field. Previous studies on antimicrobials obtained from natural sources have focused on Spirulina platensis, Chrococcus sp., Oscillatoria sp., Synechocystis aquatilis, Anabaena sp., Oscillatoria limosa, Pseudoanabaena limnetica, Phormidium tenue and Spirulina platina species (Özdemir, Karabay, Dalay, \& Pazarbaș, 2004; Demiriz, Çökmüş, \& Pabuçcu, 2011). As can be seen above, the antimicrobial properties of cyanobacteria have been studied in different species, but a study on Dolichospermum affine has not been found in the literature. This research investigated the antibacterial activity of cyanobacteria $D$. affine extracts against five selected pathogenic bacteria.

\section{MATERIALS AND METHODS}

\section{Sample isolation}

In our previous studies, D. affine was isolated in samples collected from various freshwater resources in Ankara, Turkey. The one-cell growth technique was used for the isolation of strains (Parvin, Zannat, \& Habib, 2007). Taxonomic identification of the isolate was based on morphological features and species keys (Prescott 1973; John, Witton, \& Brook, 2002; Guiry \& Guiry 2018). The subcultures

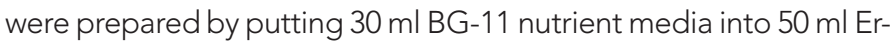
lenmeyer flasks and adding approximately $20 \%$ culture depending upon the intensity of cells (Hur, Bae, Youn, \& Jo, 2015). BG-11 medium contained (in g/L) $\mathrm{NaNO}_{3}, 1.5 ; \mathrm{K}_{2} \mathrm{HPO}_{4}{ }^{\prime} 0.04 ; \mathrm{MgSO}_{4} \cdot 7 \mathrm{H}_{2} \mathrm{O}$, 0.075; $\mathrm{CaCl}_{2} \cdot 2 \mathrm{H}_{2} \mathrm{O}, 0.036$; citric acid, 0.006; ferric ammonium citrate, 0.006; EDTA, $0.001 ; \mathrm{Na}_{2} \mathrm{CO}_{3^{\prime}}$ 0.02. This medium was amended with $1 \mathrm{ml}$ trace solution of composition (in $\mathrm{g} / \mathrm{L}$ ) $\mathrm{H}_{3} \mathrm{BO}_{3^{\prime}}$ 2.86; $\mathrm{MnCl}_{2}, 1.81 ; \mathrm{ZnSO}_{4} \cdot 7 \mathrm{H}_{2} \mathrm{O}, 0.222 ; \mathrm{Na}_{2} \mathrm{MoO}_{4} \cdot 2 \mathrm{H}_{2} \mathrm{O}, 0.39 ; \mathrm{CuSO}_{4} \cdot 5$ $\mathrm{H}_{2} \mathrm{O}, 0.079$; and $\mathrm{Co}\left(\mathrm{NO}_{3}\right)_{2} \cdot 6 \mathrm{H}_{2} \mathrm{O}, 0.0494$ (UTEX, 2016). All the chemicals were obtained from Merck, Germany. The $\mathrm{pH}$ was adjusted to 6.8 (Andersen \& Kawachi, 2005). Those containing $30 \mathrm{ml}$ cultures were incubated at $25^{\circ} \mathrm{C}$ under fluorescent lamps at a photon flux density of $50 \mu \mathrm{mol}$ photons $\mathrm{m}^{-2} \mathrm{~s}^{-1}$ with a photocycle of light for 16 hours and darkness for 8 hours (Guillard, 2005).

\section{Cyanobacteria culture}

D. affine was cultivated in BG-11 culture medium and the experiments were carried out in $500 \mathrm{ml}$ Erlenmeyer flasks containing $200 \mathrm{ml}$ of medium and $50 \mathrm{ml}$ suspended culture at room temperature. Light was provided by cool-white fluorescent lamps at photon flux density of $50 \mathrm{\mu mol}$ photons $\mathrm{m}^{-2} \mathrm{~s}^{-1}$ with a photocycle of a light for 16 hours and darkness for 8 hours for 14 days (Guillard, 2005). After culturing, the cells of $D$. affine were centrifuged at $5000 \mathrm{rpm}$ for $20 \mathrm{~min}$ (Nüve NF 200), the supernatant was discarded, and the remaining pellets were then used to test the effect of the algal extracts on some bacteria strains.

\section{Preparation of algal extracts}

Approximately one gram of dried powder of $D$. affine pellets was extracted with chloroform, methanol and water $(10 \mathrm{ml})$ and shaking overnight for complete extraction. The extract was filtered and the filtrate was concentrated under reduced pressure at $37-40^{\circ} \mathrm{C}$ and stored in a refrigerator till further use. The concentration was adjusted to $1 \mathrm{mg} / \mathrm{ml}$ using the same solvent used for extraction was assayed for antibacterial activity (Malathi, Ramesh Babu, Mounika, Snehalatha, \& Digamber Rao, 2014; Deshmukh \& Puranik, 2012).

\section{Test microorganisms}

In vitro antibacterial studies were carried out against the 5 human pathogen bacteria as shown in Table 1. Nutrient Broth was used to grow these cultures and incubated at $30 \pm 1^{\circ} \mathrm{C}$ overnight.

Table 1. Test organisms.

\begin{tabular}{lll}
\hline Human Pathogen Bacteria & Code & Type \\
\hline Pseudomonas aeruginosa & ATCC 27853 & gm negative \\
Shigella dysenteria & ATCC 11835 & gm negative \\
Escherichia coli & ATCC 25924 & gm negative \\
Staphylococcus aureus & ATCC 29213 & gm positive \\
Bacillus subtilis & ATCC 6633 & gm positive
\end{tabular}




\section{Antibacterial assay}

The antibacterial activity test was done using the agar well diffusion method (Perez, Pauli, \& Bazerque, 1990). $0.1 \mathrm{ml}$ of diluted inoculum $\left(10^{5} \mathrm{CFU} \mathrm{ml}^{-1}\right)$ of the bacterial strains were swabbed on agar plates, and $5.0 \mathrm{~mm}$ size diameter wells on agar plates were made with a sterile cork borer $(5.0 \mathrm{~mm})$. Using a micropipette, $100 \mu \mathrm{l}$ of algal extract was added to the wells made on each plate. The plates were allowed to incubate at $37 \pm 2^{\circ} \mathrm{C}$ for 24 to 48 h. Antibacterial activity was assessed by measuring the zone of inhibitions ( $\mathrm{mm}$ ) against the bacterial strains. Negative controls were prepared using the same solvents employed to dissolve the obtaining extracts. Gentamycin $(10 \mu \mathrm{g})$ and Ampicillin $(10 \mu \mathrm{g})$ antibiotic discs were used as a positive reference standard to determine the sensitivity of one strain from each bacterial species. The tests were performed in triplicate. The following antimicrobial index formula was used to compare the antimicrobial activity of the sample with the activity of the standard (Malathi et al., 2014):

Antimicrobial Index $=($ Extract inhibition zone/Antibiotic inhibition zone) $\times 100$

\section{Statistical analysis}

The results were presented as mean values \pm standard deviation. The standard deviations were calculated using Microsoft Excel.

\section{RESULTS AND DISCUSSION}

Dolichospermum affine (Lemmermann) Wacklin, L. Hoffmann \& Komárek is a Cyanobacteria which belongs to the family Aphanizomenonaceae of class Cyanophyceae and this is a freshwater species. Fig. 1 presents the taxonomic classification (left) of $D$. affine (Guiry \& Guiry, 2018) and its appearance under a microscope (right).

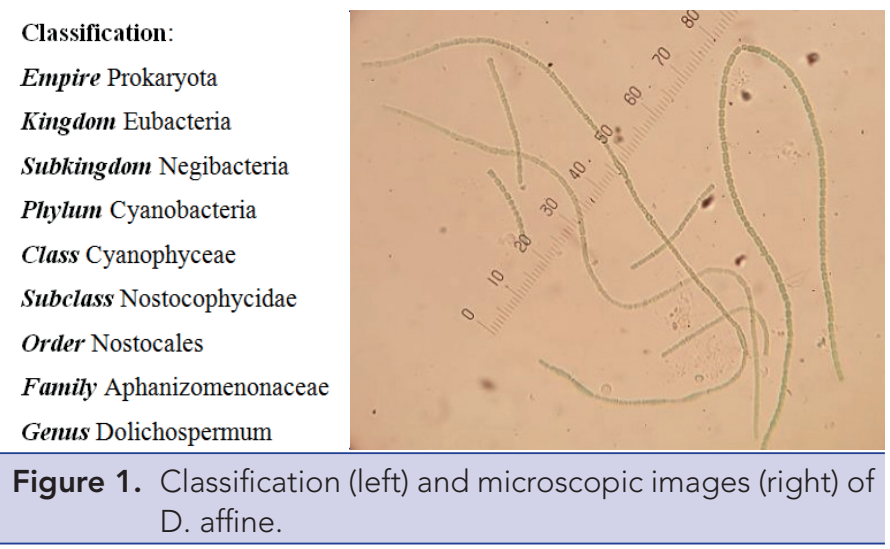

Cyanobacteria produce different bioactive compounds with antibacterial, antifungal, antiviral, and anti-inflammatory properties of industrial, therapeutic and agricultural importance (Sethubathi \& Prabu, 2010). The discovery that extracts from cyanobacteria have antimicrobial activity has shown that Cyanobacteria can be an important source in obtaining new bioactive compounds in the pharmaceutical field (Thajuddin \& Subramanian, 2005). In the study of Sethubati \& Prabu (2010) with the extracts they obtained from Oscillatoria sp., Phormidium sp. and Lyngbya majuscule;
Oscillatoria sp. showed the highest antibacterial activity and L. majuscule the lowest. In the study of Abd El-Aty et al., (2014) with Anabaena sphaerica and Oscillatoria agardhii, they found that these species showed antibacterial activity against some Gram-negative and Gram-positive bacteria. In this study, the results of antibacterial activity of the $D$. affine against two Gram-positive and three Gram-negative bacterial strains are shown in (Table 2). It is obvious that the diameter of the inhibition zone (DIZ) depends on the type of algal species, the kind of solvent used and the tested pathogenic microorganisms. In the present study, extracts of $D$. affine were used with three different solvents, namely methanol, chloroform and aqueous extracts. The mean values of three replicates of the DIZ (in millimeters) around each well with different extracts are also given in Table 2 . $D$. affine extracts confirmed antibacterial activities against four tested pathogenic bacteria out of five pathogenic bacterial strains. Methanol extracts exhibited better antibacterial activities than chloroform extracts. According to DIZ results, Bacillus subtilis and Escherichia coli were more sensitive, while Staphylococcus aureus and Pseudomonas aeruginosa showed more intermediate results. The highest antimicrobial activity was measured against $E$. coli $[D I Z=13.9 \pm 0.05 \mathrm{~mm}$ (methanol) and $\mathrm{DIZ}=13.8 \pm 0.01$ $\mathrm{mm}$ (chloroform)], followed by $B$. subtilis $[D I Z=13.6 \pm 0.05 \mathrm{~mm}$ (methanol) and $\mathrm{DIZ}=13.5 \pm 0.06 \mathrm{~mm}$ (chloroform)] (Fig. 2). D. affine's chloroform extract showed the lowest antibacterial effect in both $P$. aeruginosa ( $D I Z=11.7 \pm 0.02 \mathrm{~mm}$ ) and $S$. aureus $(\mathrm{DIZ}=12.2 \pm 0.03 \mathrm{~mm}$ ). The Gram-negative bacteria $S$. dysenteria exhibited no zone of inhibition. The aqueous extract showed poor activities against the tested pathogenic bacteria. Chloroform, Methanol, Distilled water negative control also showed no inhibitory effect, while the positive control (Gentamicin and Ampicillin) showed inhibition diameters ranging from 13.0 to 27.0 $\mathrm{mm}$ and 13.0 to $26.0 \mathrm{~mm}$ respectively.

The antibacterial effects of the $D$. affine extracts were compared with commercial antibiotics and the results of this comparison are given in (Table 3) as the antimicrobial index. According to the index data, the efficacy of the chloroform and methanol extracts obtained from D. affine, especially on E. coli, were 63\% and $66 \%$ similar to the efficacy of currently used antibiotics. It can be concluded that $D$. affine is an alternative to current commercial applications as an antibacterial agent in phytotherapy.

Halder (2015) tested the antibacterial effects of Anabaena variabilis extracts in different solvents against the eight pathogenic bacterial strains out of which three are Gram positive (Bacillus subtilis, Micrococcus luteus and Staphylococcus aureus) and five are Gram negative bacteria (Escherichia coli, Pseudomonas aeruginosa, Shigella dysenteriae, Shigella flexneri and Vibrio cholerae) using the agar well diffusion method. It was found that the results obtained from the same solvent and bacteria used in the study by Halder (2015) were similar to the results in this study. In the study conducted by Abobaker \& Elsalhin (2019), extracts of Anabaena circinalis in different concentrations (25, 50, 75 and 100\%) were tested to determine the efficacy against four bacterial strains (Achromobacter xylosoxidans, Staphylococcus aureus, Escherichia coli, Shigella dysenteriae). Results showed that the highest level of antimicrobial activity was recorded against $S$. dysenteriae at 
Table 2. The diameter of inhibition zone (DIZ) of the different solvent extracts of $D$. affine.

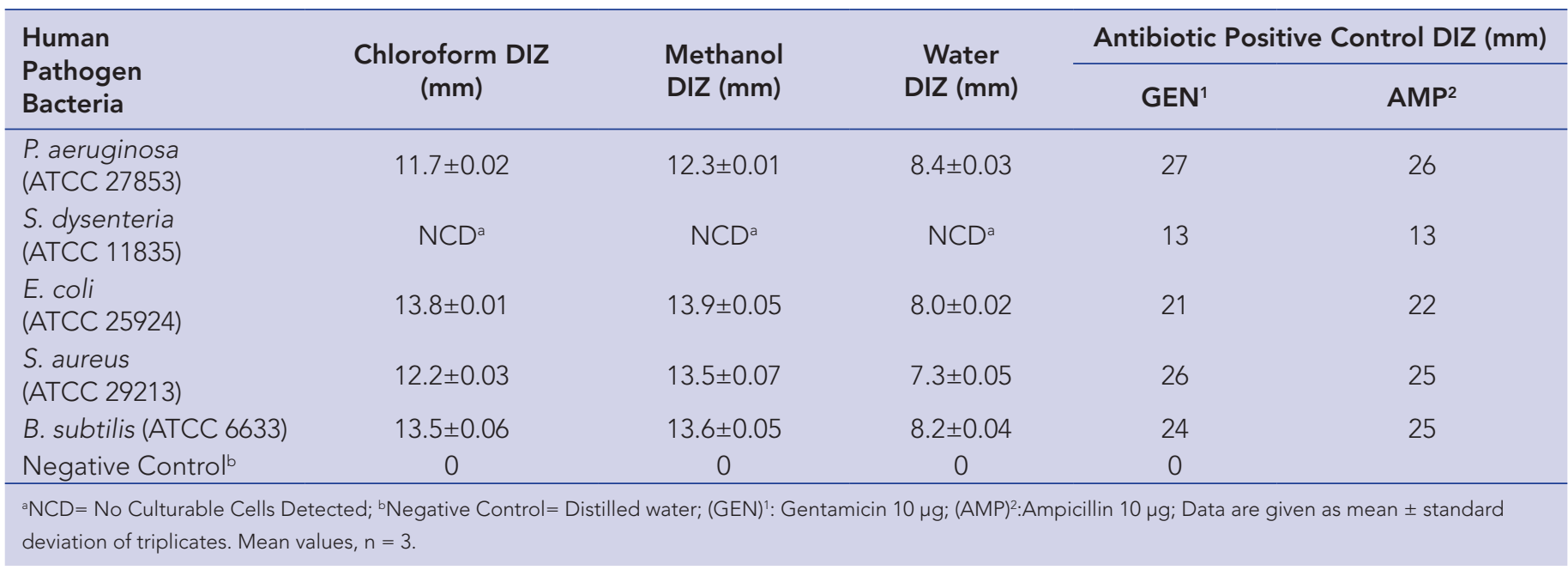

Table 3. Antimicrobial index of $D$. affine extracts.

\begin{tabular}{lcccc}
\hline \multirow{2}{*}{$\begin{array}{l}\text { Human } \\
\text { Pathogen } \\
\text { Bacteria }\end{array}$} & Antibiotics & \multicolumn{3}{c}{$\begin{array}{c}\text { Antimicrobial Index in Per- } \\
\text { centage }\end{array}$} \\
\cline { 5 - 6 } & & $\begin{array}{c}\text { Chloro- } \\
\text { form }\end{array}$ & $\begin{array}{c}\text { Metha- } \\
\text { nol }\end{array}$ & Water \\
\cline { 1 - 1 } P. aeruginosa & GEN & 43 & 46 & 31 \\
(ATCC 27853) & AMP & 45 & 47 & 32 \\
S. dysenteria & GEN & NCD & NCD & NCD \\
(ATCC 11835) & AMP & NCD & NCD & NCD \\
E. coli & GEN & 66 & 66 & 38 \\
(ATCC 25924) & AMP & 63 & 63 & 36 \\
S. aureus & GEN & 47 & 52 & 28 \\
(ATCC 29213) & AMP & 49 & 54 & 29 \\
B. subtilis & GEN & 56 & 57 & 34 \\
(ATCC 6633) & AMP & 54 & 54 & 33 \\
\hline
\end{tabular}

NCD $=$ No Culturable Cells Detected - (GEN) Gentamicin $10 \mu g$; (AMP) Ampicillin $10 \mu \mathrm{g}$

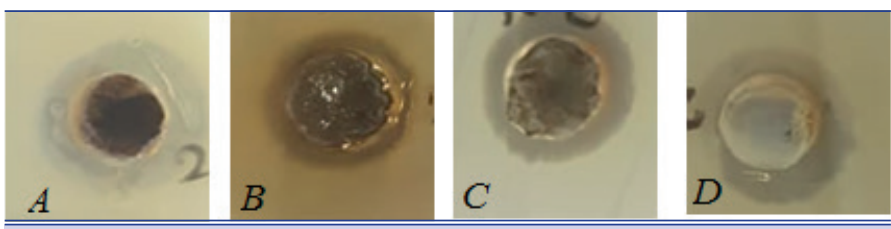

Figure 2. Inhibition zone of some pathogen bacteria (methanol extracts) [A. P. aeruginosa (ATCC 27853);

B. E. coli (ATCC 25924); C. S. aureus (ATCC 29213);

D. B. subtilis (ATCC 6633)].

$100 \%$ concentration. However, in this study, the extracts in different solvents of $D$. affine against $S$. dysenteriae did not cause any antibacterial effect. It is thought that this may be caused by the species used in the studies and the different solvents.
Compounds obtained from cyanobacterial extracts with antimicrobial and antitumoral activity worldwide are attracting a great deal of attention. Mtolera \& Semesi (1996) stated that these components include amino acids, terpenoids, fluorotannins, steroids, phenolic compounds, halogenated ketones and alkanes, cyclic polysulfides and fatty acids. Cyanobacter extracts are usually obtained with organic solvents such as methanol, hexane, chloroform, ethanol, acetone, diethyl ether, butanol and DMSO (Shamchi, 2016). For substances extracted by means of these solvents, Cowan (1999) suggests that these substances can be either terpenoid or flavonoid. In this study, it can be thought that the active substance acting on test bacteria may be terpenoid or flavonoid, however, further analysis is required to say this.

Antibiotic-resistant bacterial species are serious threats to animal and human health and cause serious damage. Clinical studies on the resistance mechanism of bacteria have enabled the identification of clinical uses of all antimicrobial agents (Helms, Vastrup, Gerner-Smidt, \& Molbak, 2002). Due to increased bacterial resistance to commercial standards and reserve antibiotics, it is important to search for new active substances with antibacterial activity (Abobaker \& Elsalhin, 2019). In this context, Cyanobacteria have started to be seen as promising sources in the production of antimicrobial substances due to their biologically active substances. Extracts of different Cyanobacteria species obtained by different solvents exhibited different degrees of antimicrobial activity on pathogenic microorganisms and have been studied by different researchers. In the study conducted by Tiwari \& Sharma (2013), cyanobacterial extracts of Anabaena variabilis and Synechococcus elongates showed a significant antibacterial ratio against Enterococcus sp., Klebsiella sp. and E. coli. Malathi et al., (2014) observed significant antibacterial activities of Anabaena variabilis in chloroform and methanol crude extracts against $B$. subtilis and $P$. aeruginosa. Rania \& Taha (2008) reported that Spirulina platensis extracts from different solvents show different degrees of antimicrobial activity on both Gram-positive and Gram-negative microorganisms. 


\section{CONCLUSION}

In this study, it was found that extracts of $D$. affine strain obtained using different solvents have pharmaceutically interesting bioactive compounds. The cyanobacterial extracts obtained showed antibacterial properties against tested pathogenic bacteria, except $S$. dysenteria. The present research has shown that the antimicrobial activity of cyanobacterial strains is dependent on the solvents used to make the extracts and the effect of these solvents. Therefore, it is suggested that more detailed studies should be conducted to confirm the effect of antimicrobial activity of crude extracts prepared from different solvents. The future studies aim to identify the bioactive components responsible for antimicrobial effect from cyanobacterial strains by purification. It is thought that the findings obtained from this study can be used for future research and for the production of antibacterial drugs of cyanobacterial origin.

Conflict of interest: The author declares no conflict of interest.

Ethical approval: This article does not contain any studies with animals.

\section{REFERENCES}

Abd El-Aty, A. M., Mohamed, A. A. \& Samhan, F. A. (2014). In vitro antioxidant and antibacterial activities of two fresh water Cyanobacterial species, Oscillatoria agardhii and Anabaena sphaerica. Journal of Applied Pharmaceutical Science, 4(7), 69-75.

Abobaker, H. M. \& Elsalhin, H. E. L. (2019). Antibacterial Activity of Anabaena circinalis Isolated from Fresh Water. Journal of Advances in Microbiology, 15(3), 1-7. [CrossRef]

Andersen, R. A. \& Kawachi, M. (2005). Traditional microalgae isolation techniques. In R. A. Andersen (Ed), Algal culturing techniques (pp. 83-100). London, Elsevier Press. [CrossRef]

Brennan, L. \& Owened, P. (2010). Biofuels from microalgae A review of technologies for production, processing and extractions of biofuels and co-products. Renewable and Sustainable Energy Reviews, 14(2), 557-577. [CrossRef]

Converti, A., Casazza, A. A., Ortiz, E. Y., Perego, P. \& Borghi, M. D. (2009). Effect of temperature and nitrogen concentration on the growth and lipid content of Nannochloropsis oculata and Chlorella vulgaris for biodiesel production. Chemical Engineering and Processing: Process Intensification, 48, 1146-1151. [CrossRef]

Cowan, M. M. (1999). Plant products as antimicrobial agents. Clinical Microbiology Reviews, 564-582. [CrossRef]

Demir, Ö. (2011). Neochloris pseudoalveolaris Deason \& Bold'de biyomas artışı ve yağ üretiminin araştırılması. Ege Üniversitesi Fen Bilimleri Enstitüsü, Yüksek Lisans Tezi.

Demirbas, A. (2010). Use of algae as biofuel sources. Energy Conversion Management, 51(12), 2738-2749. [CrossRef]

Demiriz, T., Çökmüş, C. \& Pabuçcu, K. (2011). Antimicrobial activity of some algal species belonging to cyanobacteria and chlorophyta. Asian Journal of Chemistry, 23(3), 1384-1386.

Deshmukh, D. V. \& Puranik, P. R. (2012). Application of plackett-burman design to evaluate media components affecting antibacterial activity of alkaliphilic cyanobacteria isolated from Lonar Lake. Turkish Journal of Biochemistry, 35(2), 114-120.

Gault, P. M. \& Marler, H. J. (2009). Handbook on cyanobacteria: biochemistry, biotechnology and applications. New York: Nova Science Publishers.

Guillard, R. R. L. (2005). Purification methods for microalgae. In R.A. Andersen (Ed.), Algal culturing techniques (pp. 117-132). London, Elsevier Press. [CrossRef]
Guiry, M. D. \& Guiry, G. M. (2018) AlgaeBase. World-wide electronic publication, National University of Ireland, Galway. Retrieved from http://www.algaebase.org. (accessed 21.10.18)

Gouveia, L. (2014) From tiny microalgae to huge biorefineries. Oceanography. [CrossRef]

Gouveia, L., Batista, A. P., Sousa, I., Raymundo, A. \& Bandarra, N. M. (2008). Microalgae in novel food products. In K.N. Papadopoulos \& N.Y. Hauppauge, (Eds.), Food Chemistry Research Developments (pp. 1-37). Nova Science Publishers. ISBN 978-1-60456-262-0.

Halder, N. (2015). Phytoconstituents composition and in vitro antibacterial activity of a blue green alga Anabaena variabilis Kütz. ex Born. et Flah. Tropical Plant Research, 2(3), 288-291.

Helms, M., Vastrup, P., Gerner-Smidt, P. \& Molbak, K. (2002). Excess mortality associated with antimicrobial drug-resistant Salmonella typhimurium. Emerging Infectious Diseases, 8, 490-495. [CrossRef]

Hur, S. B., Bae, J. H., Youn, J. Y. \& Jo, M. J. (2015). KMMCC-Korea marine microalgae culture center: list of strains, 2nd edition. Algae, S1-S188. [CrossRef]

John, D. M., Witton, B. A. \& Brook, A. J. (2002). The Freshwater Algal Flora of the British Isles. UK: Cambridge.

Kreitlow, S., Mundt, S. \& Lindequist, U. (1999). Cyanobacteria - a potential source of new biologically active substances. Progress in Industrial Microbiology, 35, 61-63. [CrossRef]

Lorenz, R. T. \& Cysewski, G. R. (2000). Commercial potential for Haematococcus microalgae as a natural source of astaxanthin. Trends Biotechnology, 18(4), 160-167. [CrossRef]

Madigan, T. M., Martinko, J. M., Stahl, D. A. \& Clark, D. P. (2012). Brock biology of microorganisms. Thirteen edition, ISBN-13: 9780321649638.

Malathi, T., Ramesh Babu, M., Mounika, T., Snehalatha, D. \& Digamber Rao, B. (2014). Screening of cyanobacterial strains for antibacterial activity. Phykos: Journal of the Phycological Society, 44(2), 6-11.

Mtolera, M. S. P. \& Semesi, A. K. (1996). Antimicrobial activity of extraxts from six green algae from Tanzania. Current Trends In Marine Botanical Research In East African Region, 211-217.

Mulbry, W., Kondrad, S. \& Buyer, J. (2008). Treatment of dairy and swine manure effluents using freshwater algae: fatty acid content and composition of algal biomass at different manure loading rates. Journal of Applied Phycology, 20, 1079-1085. [CrossRef]

Özdemir, G., Karabay, N. U., Dalay, M. C. \& Pazarbaş B. (2004). Antibacterial activity of volatile component and various extracts of Spirulina platensis. Phytotherapy Research, 18, 754-757. [CrossRef]

Parvin, M., Zannat, M. N. \& Habib, M. A. B. (2007). Two important technique for isolation of microalgae. Asian Fisheries Science, 20, 117-124.

Patil, K. J., Patil, V. A., Mahajan, S. R. \& Mahajan, R. T. (2011). Bio-activity of algae belonging to Bhusawal region, Maharashtra. Current Botany, 2, 29-31.

Perez, C., Pauli, M. \& Bazerque, P. (1990). An antibiotic assay by agar-well diffusion method. Acta Biologiae et Medecine Experimentaalis, 15, 113-115

Plaza, M., Santoyo, S. \& Jaime, L. (2010). Screening for bioactive compounds from algae. Journal of Pharmaceutical and Biomedical Analysis, 51(2), 450-455. [CrossRef]

Prescott, G. W. (1973). Algae of the western great lakes area. Michigan: C. Brown Company Publishers.

Pulz, O. \& Gross, W. (2004). Valuable products from biotechnology of microalgae. Applied Microbiology Biotechnology, 65, 635-648. [CrossRef]

Rania, M. A. \& Abedin Hala Taha, M. (2008). Antibacterial and antifungal activity of Cyanobacteria and green Microalgae, evaluation of medium components by placket-Burman Design for antimicrobial activity of Spirulina platensis. Global Journal of Biochemistry and Biotechnology, 3(1), 22-31. 
Shamchi, M. (2016). Investigation of cyanobacteria and some algal species bioactive compounds. Hacettepe Üniversitesi, Doktora Tezi.

Sethubathi, G. V. B. \& Prabu, V. A. (2010). Antibacterial activity of cyanobacterial species from Adirampattinam Coast, Southeast Coast of Palk Bay. Current Research Journal of Biological Sciences, 2(1), 24-26.

Taskin, E., Ozturk, M., Taskin, E. \& Kurt, O. (2007). Antibacterial activities of some marine algae from the Aegean Sea (Turkey). African Journal of Biotechnology, 6(24), 2746-2751. [CrossRef]

Thajuddin, N. \& Subramanian, G. (2005). Cyanobacterial biodiversity and potential applications in biotechnology. Current Science, 89(1), 47-57.

Tiwari, A. \& Sharma, D. (2013). Antibacterial activity of bloom farming Cyanobacteria against clinically isolated human pathogenic microbes. Journal of Algal Biomass Utilization, 4(1), 83-89.
UTEX Culture Collection of Algae (2016, 12 October). Retrieved October 12, 2019, from https://utex.org/products/bg-11-medium?variant= 30991786868826 (accessed 12.10.2019).

Walker, T. L., Purton, S. \& Becker, D. K. (2005). Collet C: microalgae as bioreactors. Plant Cell Reports, 24, 629-641. [CrossRef]

Weis, Y. H. \& Pang, C. Y. (2010). The role of mitochondria in human aging process. Biotechnology International, 17, 8-13.

Whitton, B. A. (2000). Soils and rice-fields. In B. A., Whitton \& M., Potts, (Eds), The Ecology of Cyanobacteria (pp. 233-255) Dordrecht: Kluwer Academic. [CrossRef] 